\title{
URBAN LANDSCAPE: FROM URBAN BEAUTIFICATION TO SUSTAINABLE LANDSCAPE DEVELOPMENT
}

\author{
ESA AHMAD \& MAZIFAH SIMIS \\ National Landscape Department, Ministry of Wellbeing, Housing and Local Government, Malaysia
}

\begin{abstract}
Increase in public awareness toward high quality living environment led landscape being seen as the important component of urban environment in Malaysia. The landscape beautification projects of protocol roads, pocket parks, urban squares, promenades and urban woodland were found to give positive impact on the quality of life of the urban area. However, issue of green space availability in urban area requires new approach. The landscape beautification project has been now changed into more integrated Urban Landscape Program (ULP). The ULP emphasizes regeneration of urban green spaces to ensure sustainability. This paper will further discuss the way forward in sustaining the urban landscape development program in Malaysia as part of the effort to create sustainable cities through effective landscape planning.

Keywords: urban landscape, landscape planning, urban green space, Landscape Master Plan, policy.
\end{abstract}

\section{INTRODUCTION}

The image of the city with adequate basic infrastructure, opportunity for employment and efficient administration attracts many inhabitants. It is expected that by the year $2030 ; 75 \%$ of the earth's population is urban population. Drastic growth in urban population will create higher needs to quality living environment and the need to uphold the concept of sustainable urban development [1]-[4].

The evolution of urban community needs towards urban green spaces for a quality living environment was started with the development of Central Park as the green heart of New York [5]. Central Park success stories increase the global public awareness towards the importance of urban green spaces. Since then, urban green spaces became the indicator for the sustainable and liveable city [4]. With this regard, Malaysia as a member of Group 1 developing countries in Southeast Asia with urbanization rate more than 70\% [6], is no exception. Rapid migration of rural population to urban areas is expected to create cities as the habitat for 2/3 of Malaysia's population in the year 2030 [7]. This phenomenon has increased the urban built-up area and cause impact to the existing urban green spaces. As for example, the capital city of Malaysia; Kuala Lumpur with $92.6 \%$ built-up area is now facing a critical problem of inadequate urban green spaces [8]. Similar situation has also happened in most town and cities in the country.

\section{LANDSCAPE DEVELOPMENT IN MALAYSIA}

The landscape evolution in Malaysia could be divided into three phases, namely the preindependence era, the post-independence of the 60 s and the 90 s era.

\subsection{Landscape development of the pre-independence}

Prior to independence Malaysia known as Malaya was colonized by the British who brought together their way of life that emphasizes the need to urban green areas for outdoor and social recreation. The development of the Taiping Lake Garden (1880) and the Kuala Lumpur Lake Gardens (1888) by Charles Compton and Penang Botanic Gardens in 1885 by Charles Curtis 
stamped out physical evidence of their passion. These parks were exclusively used by the colonial officers as their leisure and recreation ground [9], [10].

\subsection{Landscape development in post-independence and 90s era}

After independence, Malaysia focuses exclusively on physical development. According to Hadi [11], Malaysia urbanization process was accelerated with the implementation of the New Economic Policy in 1971. Since then, green vicinity within the urban area has gradually been turned up into a built-up area to accommodate new sites for industry, commercial and settlement. Land use data showed that in Peninsula Malaysia, built-up area increased by $271.57 \%$; from $437,090.00$ hectares in the year 2001 to $1,187,003.59$ hectares in the year 2012 [12].

However, the global awareness towards the need to implement sustainable development's concept has changed Malaysia perspectives. The urban green space becomes an important component in the urban physical development. The era of the 90 s was the starting point in which landscape has officially adopted as an important component in the physical development. It was accepted as criteria in the development approval.

In the year 1997a dedicated department namely National Landscape Department (NLD) was established at federal level to oversee national landscape development in the country [13]. Since then, the Department has formulated various guidelines and procedures to be used by local authorities for effective green and open space planning and management. Various programs have been implemented in order to improve urban living quality. Among other Landscape Development program has been implemented to boost out greenery in the urban setting.

Later in the year 2010, a comprehensive National Landscape Policy has been formulated. It was approved by the government as a mean to guide all parties to contribute and venture toward making Malaysia a Garden Nation. One of its action plans is to ensure that $30 \%$ of the built-up area of towns and cities to remain green, of which $10 \%$ of the green area is to be function as open spaces.

\subsection{Landscape development program and its impact}

Landscape development program comprises of landscape of protocol roads, development of pocket parks, city squares, promenades and urban woodlands. As the main objective of the program was to increase greenery and beautifying the urban area, each project was actually localised in nature. By 2010, eighty-three projects under the program have been completed. Aiming to identify the effectiveness of the program, outcome study has been carried out [14]. A sample of thirty-three projects consist of 21 protocol roads, 5 pocket parks, 2 urban squares, 4 promenades and 1 urban woodland were selected as the study area. 8,832 users of the Landscape Development program were randomly selected as respondent. The objectives of this study were to identify (i) the level of user's satisfaction (ii) the function of the green spaces, and (iii) the user's perception towards the healthy living environment created by the projects. The findings are shown in Table 1.

The outcome of the study proves that the Landscape Development program gave positive impact to the user. In average $70.95 \%$ of the respondents says that the landscape development projects have contribute well to improve urban area by were improving environmental quality $(68.43 \%)$, as functional open spaces $(70.25 \%)$ and satisfy user's need to the green spaces $(74.09 \%)$. 
Table 1: The finding of Landscape Development program evaluation study. (Source: National Landscape Department, 2010.)

\begin{tabular}{|l|c|c|c|c|c|c|}
\hline Indicator & $\begin{array}{c}\text { Protocol } \\
\text { Roads } \\
(\%)\end{array}$ & $\begin{array}{c}\text { Pocket } \\
\text { Parks } \\
(\%)\end{array}$ & $\begin{array}{c}\text { Urban } \\
\text { Squares } \\
(\%)\end{array}$ & $\begin{array}{c}\text { Promenades } \\
(\%)\end{array}$ & $\begin{array}{c}\text { Urban } \\
\text { Woodlands } \\
(\%)\end{array}$ & $\begin{array}{c}\text { Total } \\
(\%)\end{array}$ \\
\hline $\begin{array}{l}\text { User's } \\
\text { satisfaction }\end{array}$ & 65.36 & 76.60 & 76.64 & 73.88 & 77.98 & 74.09 \\
\hline $\begin{array}{l}\text { Function of } \\
\text { urban green } \\
\text { spaces }\end{array}$ & 52.04 & 72.78 & 71.50 & 72.46 & 82.46 & 70.25 \\
\hline $\begin{array}{l}\text { Environment } \\
\text { quality }\end{array}$ & 71.34 & 63.72 & 48.84 & 71.22 & 87.02 & 68.43 \\
\hline Total (\%) & 62.91 & 71.03 & 65.66 & 72.52 & 82.62 & 70.95 \\
\hline
\end{tabular}

This finding also shows that the urban woodland was perceived by the users as the project that give highest impact to the user (82.62\%). Despite some achievement there were some issues and challenges to be solve in order to improve the program.

\subsection{Issues and challenges}

Even with an overall satisfaction score of $70.95 \%$, the Landscape Development program has faced challenging issues to ensure its sustainability. Three major issues identified were as follows:

1. Inadequate urban green spaces.

The rapid growth in the physical development of major cities of Malaysia has given impact to the existing status of urban land use. A significant number of existing green and open grounds were transformed into settlement, commercial and industrial land use. It resulted with a critical issue of inadequate urban green spaces [15]. The study by Ngah [16] found that Kuala Lumpur could only capable of providing 0.4 acres of Public Park per 1,000 urban populations; while the study by PEMANDU [17] showed that one individual of Kuala Lumpur residence could only access to 12-meter green spaces. Both of these studies proved that the inadequate urban green spaces in the Malaysia capital city, with a ratio far below the standards set by the National Physical Planning Council [18] and the World Health Organization [19].

2. Piecemeal development.

Due to nature of the landscape projects of protocol roads, pocket parks, urban squares, promenades and urban woodland, they were perceived by many as a piecemeal development which mainly for greening and beautification purposes. This perception was quite true, as the selection of the landscape development site was totally depends on the existence and the available urban green spaces. It does create an image of patching and none integrated urban fabrics.

3. The changing needs of the community towards high quality landscape development. Increasing awareness of the urban community toward the importance of external spaces as part of their living environment has made landscape being chosen as a tool to achieve high quality of life. There is a rising needs to developed urban green spaces as an integrated area for a specific urban development [14]. It means no more piecemeal projects for beautification purposes. 


\section{URBAN LANDSCAPE - CHANGING FABRIC IN LANDSCAPE PLANNING}

Aiming to address the three main issues identified, the Urban Landscape program was initiated in the year 2014. Urban Landscape Program is an integrated development project aimed to connect the urban nodes, green areas, and recreational areas through green linkages. The implementation of the Urban Landscape program changes the landscape planning pattern within the urban area. This impact derived from the compliance of:

\section{1. $\quad$ Landscape Master Plan (LMP)}

Landscape Master Plan is a landscape planning document developed by the NLD for the Local Authority in Malaysia. It covers the entire administrative area of the Local Authority, especially the city centre and its urban area. It is to ensure that the particular Local Authority will have a unique and distinct identity, capable to preserve and conserve its natural resources and landscape character. The proposed landscape development will contribute beneficial value to the economic, social and environment. In simple words, Landscape Master Plan is a translation of sustainable development and sustainable city concepts based on the Malaysia's perspective through efficient landscape planning. Based on the LMP, the Local Authority will be able to identify potential areas for Urban Landscape program. As for example - the Tawau Municipal Council Landscape Master Plan (Fig. 1) has identified three main recreation nodes which located at the northern, central and eastern zone. Through proper design of green linkages, these three nodes can be used to create a potential area for various purposes.

\section{Current policy}

It is very important for any development programs to be accepted by the stakeholder to ensure its sustainability [21]. Due to this fact, the Urban Landscape program is designed, implemented and regulated by the current Government's policies such as the National Landscape Policy, the National Urban Policy and the policy of the National Physical Planning Council. Thrust 3 the National Landscape Policy states the need to 'create landscape development programs to provide functional and sustainable green infrastructure' [22]. Meanwhile the importance to provide adequate provision of urban green spaces was stated in Trust 5 National Urban Policy in 'creation of a liveable urban living environment with its own identity' [23]. Both of these policies were the reflection of Malaysia vision toward achieving the Garden Nation. This vision is in line with the decision of the National Physical Planning Council as to provide 2 hectares of open spaces per 1,000 urban populations [18].

To comply with the National Landscape Policy and the current approach of implementation, the National Landscape Department is in progress of completing six Urban Landscape projects. Urban Landscape of Cameron Highland, Pekan, Batu Pahat, Tawau, Bintulu and Alor Setar will be completed by the year 2018. Every project has been designed to address pertinent issues of the Particular Township and urban community such as urban heat island, scarcity of green and open spaces, recreational access, and connectivity and walk ability. The design of the Urban Landscape project has also aims to uplift community socioeconomic and culture. This is to gain ownership of the urban community as to ensure the sustainability of the project. 
Pelan Induk Landskap Majis Perbandaran Tawau

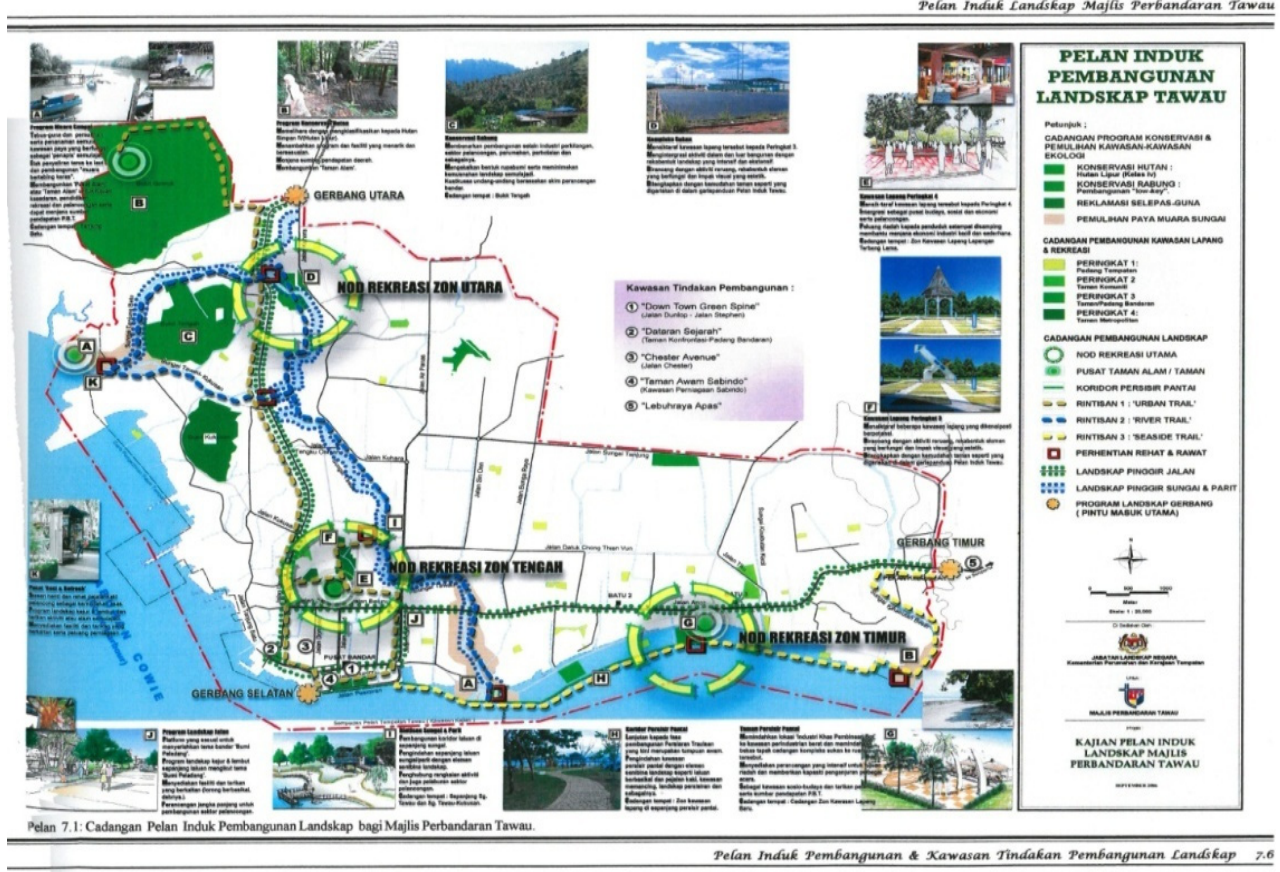

Figure 1: Landscape Master Plan of Tawau Municipal Council. (Source: National Landscape Department, 2005).

\section{WAY FORWARD - SUSTAINABLE URBAN LANDSCAPE DEVELOPMENT}

Providing a sustainable living environment is a prerequisite towards creating high quality urban wellbeing. It ensures disaster-free and healthy surrounding that could full-filling a right to have clean air and water, healthy food and access for recreation. It could only be achieved by adhering to the principle of respecting all components in the urban living environment. All these principles have been given due consideration in implementing Urban Landscape program. As a way forward, Urban Landscape program will be implemented in all cities in Malaysia. This program will not only solve issues of inadequate urban green spaces but act as a tool preserve and conserve natural resources, rehabilitating disturbed land, enhancing environmental components as well as creating a new opportunity of green and open spaces. It will also help in addressing socioeconomic demands of the urban spaces and creating a specific urban identity.

\section{CONCLUSION}

Inadequate urban green spaces will always be an ongoing issue in line with the rapid urbanization. It needs to be addressed in a holistic and integrated manner. Hence, the Urban Landscape program should be implemented to increase effective urban green spaces. It should also be seen as the landscape planning manifestation to achieve urban sustainability. It is hoped that the Urban Landscape program could sustain urban wellbeing through effective landscape planning approach. 


\section{ACKNOWLEDGEMENTS}

On behalf of the National Landscape Department, we would like to thank the Ministry of Wellbeing, Housing and Local Government, The Economic Planning Unit and the Ministry of Finance for supporting the Urban Landscape Program.

\section{REFERENCES}

[1] Katiman, R., Urbanization and issues. Kuala Lumpur: Mahakarya Press, 1983.

[2] Costanza, R., Fisher, B. \& Ali, S. 2007. Quality of life: An approach integrating opportunities, human needs and subjective well-being. Ecological Economics 61, pp. 267-276, 2007.

[3] Shaharuddin, I., Hadi, A.S. \& Shah, A.H.H., Urban physical pattern and city liveability. Akademika, 79, pp. 19-42, 2010.

[4] UN-HABITAT (United Nations Human Settlement Programme). Sustainable urbanization in Asia: A sourcebook for Local Government. IUTC, 2012.

[5] Lewis, C.A., Effects of plants and gardening in creating interpersonal and community wellbeing. In. Relf, D. eds., Role of horticulture in human wellbeing and social development: A national symposium: 55-65. Arlington: Timber Press, pp. 55-65, 1992.

[6] Liu, Q., Urbanization and urban poverty in Southeast Asia. Beijing: The International Poverty Reduction Center, 2013.

[7] Statistic Department of Malaysia Population and housing survey in Malaysia. Kuala Lumpur: National Printing Department, 2012.

[8] Rahman, H.A., Urban sprawl and its implication. Proceeding: 6th International Conference - Ecology, Human Habitat \& Environmental. Bangi: Universiti Kebangsaan Malaysia, 2013.

[9] Bakar, J.A., A design guide for Public Park in Malaysia. Johor: Universiti Teknologi Malaysia.

[10] Moore, W.K., Malaysia: A pictorial history 1400-2004. Kuala Lumpur: Archipelago Press, 2004.

[11] Hadi, A.S., Urbanization Malaysia: Assessing process in urban pattern. Malaysia Journal of Environmental Management, 11(2), pp. 21-31, 2012.

[12] PLANMalaysia. Planning guideline for brownfield redevelopment. Kuala Lumpur: PLANMalaysia, 2012.

[13] National Landscape Department. Annual Report 2016. Kuala Lumpur: Jabatan Landskap Negara, 2016.

[14] National Landscape Department. 2010. Outcome study: Landscape Development Program. Presented at Economic Planning Unit Meeting, Kuala Lumpur, Prime Minister Department, 2010.

[15] Jelani, A.M., Planning for garden city. In. Towards Garden Nation: Vision and challenges. Kuala Lumpur: Institute of Landscape Architect Malaysia, 1999.

[16] Ngah, I., Landscape in Malaysia: Towards Garden Nation. In. Towards Garden Nation: Vision and challenges. Kuala Lumpur: Institute of Landscape Architect Malaysia, 1999.

[17] PEMANDU. Economic Transformation Programme: A roadmap for Malaysia. Putrajaya: Prime Minister Department, 2010.

[18] National Physical Planning Council National Physical Planning Meeting Report No. 2/2004, 2004.

[19] WHO (World Health Organization). Urban planning, environment and health: From evidence to policy action. http://who.euro.who.int. Accessed on: 15 Aug. 2017. 
[20] National Landscape Department. Landscape Master Plan - Tawau Municipal Council. Kuala Lumpur: National Landscape Department, 2004.

[21] Mattew, C., Tim, W., Taner, O. \& Steve, T., Public places urban spaces: The dimensions of urban design. Burlington: Architectural Press, 2003.

[22] National Landscape Department. National Landscape Policy. Kuala Lumpur: National Landscape Department, 2010.

[23] PLANMalaysia. National Urban Policy. Kuala Lumpur: PLANMalaysia, 2016. 